\title{
EKSPLORASI DAN EKSPERIMENTASI DALAM KARYA SENI KRIYA KONTEMPORER
}

\author{
Andono dan Rispul*)
}

\begin{abstract}
ABSTRAK
Bersamaan dengan perubahan dan kemajuan dalam dunia seni kriya, telah banyak dilakukan eksplorasi dan eksperimentasi oleh para kriyawan di dalam penciptaan karya-karyanya. Eksplorasi dan eksperimentasi banyak dilakukan pada berbagai aspek, seperti dalam pemilihan sumber-sumber ide atau dasar-dasar penciptaan yang tidak hanya berorientasi pada aspek fungsional saja, tetapi telah banyak digali potensi-potensi sumber ide dari berbagai aspek kehidupan masyarakat. Banyak karya yang merupakan hasil dari eksplorasi dan eksperimentasi yang merepresentasikan gejala-gejala atau fenomena-fenomena yang berkembang di masyarakat. Perkembangan seni kriya, tersebut menunjukkan adanya dinamika yang menarik, Karya-karya kriya yang dahulu hanya berorientasi pada segi fungsional praktis dan keindahan ornamentasi saja, sekarang menunjukkan adanya fenomena perubahan ke karya-karya yang lebih dinamis, konseptual, kreatif dan inovatif.

Karya seni kriya kontemporer dimaksudkan sebagai karya yang sedang berkembang di masa kini, yang dalam penelitian ini akan dibatasi pada karya yang dibuat antara tahun 2007 s.d 2012, sekaligus sebagai populasinya. Adapun sebagai sampel dalam penelitian ini adalah berupa beberapa karya perwakilan dari masing-masing kriyawan yang karyanya pernah diikut sertakan dalam pameran-pameran seni kriya kontemporer. Penelitian diawali dengan penelusuran sumber kepustakaan yang berkaitan dengan topik penelitian baik yang membahas tentang seni rupa dan atau seni kriya kontemporer. Selanjutnya dilakukan observasi pendahuluan dengan mengidentifikasi kriyawan yang karya-karyanya termasuk dalam kategori seni kriya kontemporer yang pernah diikutsertakan dalam pameran seni kriya dalam kurun waktu lima tahun terakhir, dan hasilnya dijadikan sebagai populasi. Dari sejumlah populasi yang ada (kriyawan dan karyanya) dari masing-masing kriyawan diambil satu karya yang representatif sebagai sampel yang diteliti. Cara analisis data akan menyesuaikan dengan jenis data yang diperoleh dari pengumpulan data yang dilakukan. Tedapat dua jenis data yang akan diperoleh yaitu berupa data visual berbentuk foto dan diskripsi dari karya seni kriya yang diteliti. Sifat data yang akan diperoleh adalah diskriptif, maka metode analisis data yang digunakan adalah diskriptif analitik. Analisis data dilakukan dengan menggunakan metode pendekatan estetik. Analisis data akan dilakukan terhadap aspek-espek yang berkaitan dengan struktur, fungsi, dan gaya karya seni kriya kontemporer.

Penelitian ini akan menghasilkan deskripsi tentang struktur, fungsi, dan gaya karyakarya seni kriya kontemporer. Bagaimana proses kreatif dalam penciptaan meliputi: latar
\end{abstract}

\footnotetext{
* Andono dan Rispul (andono_and@yahoo.com), Staf Pengajar Jurusan Kriya Fakultas seni Rupa Institut Seni Indonesia Yogyakarta
} 
belakang penciptaan karya, metode penciptaan, metode perwujudan, media dan teknik perwujudan karya, bentuk karya yang dihasilkan, dan kandungan maknanya. Hasil penelitian ini akan sangat bermanfaat bagi para mahasiswa seni kriya maupun para pemerhati seni kriya dalam memahami bagaimana proses kreatif dalam penciptaan karya seni kriya.

Kata kunci: eksplorasi, eksperimentasi, kriya kontemporer.

\section{PENDAHULUAN}

Bersamaan dengan perubahan dan kemajuan dalam dunia seni kriya, telah banyak dilakukan eksplorasi dan eksperimentasi oleh para kriyawan di dalam penciptaan karya-karyanya. Eksplorasi dan eksperimentasi banyak dilakukan pada berbagai aspek, seperti dalam pemilihan sumber-sumber idea atau dasar-dasar penciptaan yang tidak hanya berorientasi pada aspek fungsional saja, tetapi telah banyak digali potensi-potensi sumber ide dari berbagai aspek kehidupan masyarakat. Banyak karya yang merupakan hasil dari eksplorasi dan eksperimentasi yang merepresentasikan gejala-gejala atau fenomena-fenomena yang berkembang di masyarakat.

Perkembangan seni kriya, tersebut di atas menunjukkan adanya dinamika yang menarik, khususnya apabila dilihat pada karya-karya yang diciptakan oleh para seniman/kriyawan akademik, baik oleh para alumni maupun para mahasiswa Jurusan Kriya Fakultas Seni Rupa Institut Seni Indonesia Yogyakarta. Karya-karya kriya yang dahulu hanya berorientasi pada segi fungsional praktis dan keindahan ornamentasi saja, sekarang menunjukkan adanya fenomena perubahan ke karya-karya yang lebih dinamis, konseptual, kreatif dan inovatif. Banyak karya yang mencoba mengangkat kembali kekayaan seni budaya tradisional maupun gejalagejala yang sedang terjadi di masyarakat hingga permasalahan lingkungan hidup direpresentasikan ke dalam bentuk karya seni kriya kontemporer. Fenomena ini menarik untuk dikaji, terutama yang berkaitan dengan masalah-masalah: bagaimana eksplorasi dan eksperimentasi dilakukan oleh para kriyawan dalam menciptakan karyakaryanya, dan bagaimana pula bentuk karya yang dihasilkan. Selain itu, pada aspek apa saja dilakukan eksplorasi dan eksperimentasinya. Pertanyaanpertanyaan tersebut merupakan permasalahan-permasalahan yang menarik untuk dicari jawabannya melalui kajian ilmiah melalui kegiatan penelitian ini dengan judul: "Eksplorasi dan Eksperimentasi Dalam Seni Kriya Kontemporer".

Untuk melakukan kajian ilmiah tentang eksplorasi dan eksperimentasi dalam seni kriya kontemporer, diperlukan seperangkat teori yang akan dipakai sebagai dasar berpijak dalam melakukan kajian agar terhindar dari 
kemungkinan terjadinya kajian yang bias. Dalam penelitian ini yang dipakai sebagai grand theory atau teori utama adalah teori dari Edmund Burke Feldman, sedangkan teori-teori lainnya dipakai sebagai teori pendukung.

Edmund Burke Feldman dalam bukunya yang berjudul Art as Image and Idea mengemukakan teorinya dalam mengkaji karya seni melalui bebera aspek, yaitu: the function of art (personal, social, physical), the style of art (objective accuracy, formal order, emotion, fantasy) the structure of art (grammer, design, aesthetics), the interaction of medium and meaning (painting, sculpture, architectutre), art criticism (theory performance) (Feldman, 1967: 6-10).

M. Dwi Marianto mengemukakan beberapa teori yang berkaitan dengan pengkajian karya seni rupa, yang di antaranya adalah bagaimana cara mendiskripsikan karya seni. Dalam menjelaskan pengertian deskripsi, ia mengutip pendapat Terry Barret bahwa: describing atau pekerjaan mendeskripsi adalah penggambaran verbal yang dilakukan oleh seorang kritikus atas suatu karya seni sehingga ciri-ciri khusus dari suatu karya seni yang bersangkutan dapat terlihat jelas, atau diketahui, dan pada akhirnya dapat diapresiasi (Marianto, 2002: 2). Dalam mendeskripsi karya seni terdapat informasi-informasi yang bersifat internal, yaitu informasi-informasi deskriptif yang dapat dikumpulkan dari dalam karya itu sendiri; dan informasi-informasi yang bersifat eksternal, yaitu informasi yang berasal dari luar karya yang bersangkutan, seperti fakta-fakta perihal diri si seniman, atau fakta-fakta mengenai jaman ketika karya seni yang bersangkutan dibuat. Di samping itu perlu pula dikenali tiga hal utama dalam dimensi fisik karya seni yang bersangkutan, yaitu: subject matter, medium, dan form (Marianto, 2002: 3). Dalam menganalisis karya seni harus berfikir secara analitis, misalnya dengan mempertimbangkan aspek materi, judul, ukuran, pose, penempatan, ekspresi perwajahan, dan makna dari bagian-bagian karya seni bersangkutan. Prinsip dari analisis adalah dapat diketahui lebih jauh mengenai komponen-komponen karya seni yang berkait, sehingga dapat dipilih elemenelemen yang paling menarik atau bermakna untuk dibahas lebih lanjut (Marianto, 2002: 16).

Humar Sahman dalam bukunya Mengenali Dunia Seni Rupa, menguraikan beberapa pokok bahasan, yaitu : 1) tentang beberapa gambaran tentang seni yang mencakup pengertian seni dan pengertian karya seni; 2) tentang seni rupa dan cabangcabangnya; 3) gambaran selintas tentang aktivitas mencipta/kesenimanan; 4) kepengamatan, apresiasi, kritik dan estetika. Masing-masing pokok bahasan tersebut ditampilkan dalam bentuk kumpulan dari beberapa karangan atau tepatnya kutipan selektif yang diambil dari beberapa sumber yang representatif dan bisa dipertanggungjawabkan.

Di dalam memahami seni diungkapkan bahwa jika seni harus dilihat sebagai kegiatan mereproduksi realitas, maka reproduksi itu masih harus memperlihatkan campur tangan penciptanya. Seni dapat pula dilihat sebagai aktifitas mengungkap perasaan atau emosi penciptanya, sehingga menjadi karakteristik dalam arti mencerminkan kehidupan perasaan penciptanya. Selanjutnya di 
ungkapkan pula bahwa pengertian apapun yang hendak dilekatkan pada seni, maka representasi, interpretasi, kondensasi, konsentrasi, intensifikasi, konkretisasi, aktualisasi, kontemplasi, iluminasi, personifikasi; kesemuanya harus tertuang di dalam bentuk dan strukturnya (Humar Sahman, 1993: 21). Jadi apa yang disebut karya seni itu sesungguhnya dapat dilihat sebagai perpaduan antara wujud lahiriah yang bisa diamati dan perasaan terhadap nilai tertentu yang berdemensi ruhaniah. Wujud lahiriah ini lewat ciri-ciri lahiriahnya membabarkan atau mengejawantahkan sikap batin atau perasaan terhadap nilai tertentu. Begitu pula halnya dengan sikap batin itu akan memperoleh wujudnya yang harmonis secara langsung. Proses eksternalisasi yang internal secara langsung ini disebut ekspresi simbolik (Humar Sahman, 1993: 29).

Dalam buku yang sama, Humar Sahman mengutip pendapat Laura $\mathrm{H}$. Chapman dalam bukunya yang berjudul Approaches to Art in Education, mengemukakan beberapa teori yang berkaitan dengan kajian terhadap karya seni sebagai berikut.

Seni dapat dikaji dari segi-segi : a) bentuk dan dimensinya, yaitu karya dua dimensional dan karya tiga dimensional. Karya dua dimensional memiliki bentuk datar dan hanya memiliki ukuran panjang dan lebar, karena adanya optical illution maka akan kelihatan memiliki kesan volume, kedalaman dan ruang. Karya tiga dimensional memiliki bentuk yang benar-benar memakan ruang dan memiliki ukuran panjang, lebar serta tebal. Karya tiga dimensional disebut juga dengan istilah seni spasial (spatial art form) karena ketiga dimensinya harus benar-benar diperhatikan. b). Jasa atau manfaat, yaitu berkaitan dengan adanya pemilahan antara fine art dan applied art (seni murni dan seni terapan), maka termasuk dalam kelompok mana karya seni yang akan dikaji. c). Fungsi, yaitu adanya setiap karya seni yang memiliki fungsi seperti personal, sosial, pisik, politik, religius, ekonomi, pendidikan dsb. d). Medium yang digunakan, yaitu meliputi bahan, peralatan dan teknik. e). Disain sebagai struktur visual, yang terdiri dari komponen visual seperti garis, warna, bangun bentuk, sifat permukaan (texture), gelap terang (value). f). Pokok isi (subject matter) dan substansi ekspresi (expressive content), yang keduanya menunjuk pada pokok substansi karya seni yang mencakup benda atau peristiwa yang telah kita kenali melalui pengalaman kita harus diragakan secara simbolik, tematik dan interpretatif atau yang lainnya yang perlu diekspresikan. g). Gaya (style/idiom), yang mengacu pada pengertian perorangan maupun kelompok dalam periode tertentu, kebudayaan tertentu atau kawasan regional tertentu (Humar Sahman, 1993: 37-40).

Dalam buku yang sama, Humar Sahman mengemukakan juga pendapat Upjohn, dalam menelaah karya seni yang harus diperhatikan adalah segi content, expression, and decoration yang bila 
dibagankan ketiganya akan membentuk segitiga. Yang dimaksud dengan expression adalah the artist's comment on, or interpretation of, his theme (content). Yang dimaksud dengan decoration adalah formal organization in any design beyond that which may demand by content or expression (Humar Sahman, 1993: 40).

Dalam buku yang berjudul Filsafat Estetika, tulisan Wadjiz Azwar L., di antaranya mengemukakan bahwa perkembangan kriya menurut jaman awal (primitif) dan jaman klasik,

\section{Pembahasan}

keduanya bersifat tradisional kolektif dan kedaerahan. Proses pembuatannya dikerjakan secara turun temurun menururt definisi keindahan si orang pertama. Kriya tradisional yang hasil dan prosesnya mencapai puncak keindahannya akhirnya menjadi kriya klasik, sedangkan kriya jaman modern cenderung individual dan subjektif (Wadjiz Anwar, 1985).

TABEL I. FOTO DAN KONSEP KARYA SENI KRIYA KONTEMPORER

NO CAPTION FOTO KARYA KONSEP KARYA

\begin{tabular}{lll}
\hline (1) & (2) & (4) \\
\hline "hikayat \\
Ikonositas", \\
Tembaga, plat besi, \\
150x85 cm, 2007.
\end{tabular}




Rattri Yogasworo,
"berpisah",
Kain berkolin,
$90 \times 60 \mathrm{~cm}, 2007$

Aidil Adha,
"Meniti asa",
Alumunium,
Batu, $36 \times 35 \times 25$,
2007

Moch Iqbal,
"Kontra Bass"
Kuningan, besi,
kaca; 205x80x70,
2007

Setiap ada pertemuan pasti akan ada perpisahan, kejadian semacam ini juga dialami oleh Tarantula, sesudah kawin tarantula jantan akan cepat-cepat meloloskan diri dari cengkraman tarantula betina dengan maksud agar tidak dimangsa. Tarantula jantan harus cepat melarikan diri karena setelah kawin kebiasaan tarantula betina akan memakan pasangannya.

Perjalanan hidup (Proses) terkadang menghantarkan fikiran kita ke pinggir jurang yang tak diketahui kedalamanya. Bibir jurang itu yang akan membuat otak dan naluri saling mengisi untuk mengambil langkah. Langkah demi langkah yang telah ditapaki senantiasa menambah keberanian dalam meniti keinginan-keinginan yang akan dicapai untuk menentukan kearah mana kaki akan dibawa berjalan. Posisi bekicot yang sedang terhenti di tepi batu sebagai simbol jurang menyiratkan bahwasanya disaat itulah keputusan terakhir akan diambil, akankah perjalanan itu akan diteruskan dengan segala macam resikonya ataukah akan memutar arah dan menjalani tantangan yang belum bisa diprediksi.

Ruang resonansi contrabass yang
menghasilkan bunyi sebagai akibat dari dawai yang dipetik akan beda setelah ruang yang berfungsi untuk menaruh benda-benda koleksi. Seperti orang bijak, contrabass memiliki Kekuatan karakter yang tersimpan dalam bentuknya yang klasik dan eksklusif, tetapi mampu bebaur dengan berbagai instrumen musik yang mewakili jaman dan genre musik apapun menjadikan instrumen musik ini menjadi sebuah bentuk yang akrab. Proses perubahan bahan dasar yang mayoritas kayu menjadi bahan logam kaca memerlukan ketelitian dan kecakapan dalam mengerjakanya. Proses ini relatif memakan waktu, tenaga, pikiran dan biaya, contrabass mampu menyuguhkan bebagai pengalaman dan pengetahuan baru yang menarik. 


\begin{tabular}{|c|c|c|}
\hline 5 & $\begin{array}{l}\text { Mega Puspita, } \\
\text { "Reflections } \\
\text { Of Us", } \\
\text { Tembaga, besi, } \\
\text { kaca, } \\
2008\end{array}$ & $\begin{array}{l}\text { Bercermin adalah sebagai simbol bahwa } \\
\text { kita harus selalu melihat diri kita sendiri } \\
\text { untuk introspeksi, apa yang telah kita } \\
\text { lakukan sebagai khalifah diatas bumi yang } \\
\text { nantinya semua itu kita pertanggung } \\
\text { jawabkan dihadapan Allah. }\end{array}$ \\
\hline 6 & $\begin{array}{l}\text { Noor Sudiyati, } \\
\text { "Topeng } \\
\text { SangTertua } \\
\text { I",Stoneware, } 45 \times 30 \\
\mathrm{~cm}, 2008\end{array}$ & $\begin{array}{l}\text { Sebuah komunitas memiliki tokoh idola } \\
\text { yang dihormati, dihargai kebijakan- } \\
\text { kebijakannya, dan itu merupakan hukum } \\
\text { yang dianut oleh sekelompok komunitas } \\
\text { primitiff, saya gambarkan sebagai topeng } \\
\text { kepala suku yang dikelilingi oleh } \\
\text { masyarakatnya. Ter Intepretasi topeng } \\
\text { "Sang tertua" yang menampilkan sulur- } \\
\text { sulur ornamentik, sebuah tafsir atas } \\
\text { gagasan spiritual. }\end{array}$ \\
\hline 7 & $\begin{array}{l}\text { Alvi Luviani, } \\
\text { "Triangle Brooch", } \\
\text { Siver sterling, nikel, } \\
5 \times 3 \times 0.3,2008\end{array}$ & $\begin{array}{l}\text { Karya perhiasan triangle brooch adalah } \\
\text { karya seni yang menggunakan medium } \\
\text { perhiasan dengan material silver sebagai } \\
\text { salah satu penunjuk identitas sang artist } \\
\text { yang berasal dari Indonesia. Motif yang } \\
\text { digunakan adalah motif tradisional tetapi } \\
\text { ditampilkan dalam bentuk perhiasan } \\
\text { kontenporer, bentuk mengadobsi trend } \\
\text { yang ada sekaligus menjawab tantangan } \\
\text { bagaimana menghadirkan sebuah ide } \\
\text { tradisional dalam visual terkini } \\
\text { (kontemporer). Salah satu kelebihan karya } \\
\text { ini adalah dapat dipakai dalam dua cara } \\
\text { yaitu tampak depan dan tampak belekang. }\end{array}$ \\
\hline 8 & $\begin{array}{l}\text { Tamtama Hatmaka, } \\
\text { “Gelora } \\
\text { Perjuangan”,Kulit } \\
\text { tersamak,130x70 } \\
\mathrm{cm}, 2008\end{array}$ & $\begin{array}{l}\text { Orang yang berjihad selalu berhadapan } \\
\text { dengan musuh yang senantiasa } \\
\text { memberikan perlawanan dan tantangan, } \\
\text { baik langsung maupun tidak langsung. } \\
\text { Ajaran jihad itu sendiri disyariatkan untuk } \\
\text { menumbuhkan semangat juang dalam } \\
\text { menghadapi musuh. Secara historis, } \\
\text { perintah agar melakukan hijrah dari Mekah } \\
\text { ke Madinah adalah untuk menumbuhkan } \\
\text { dan mengobarkan semangat juang dalam } \\
\text { berjihad untuk menghadapi tekanan kaum } \\
\text { kafir Mekah yang anti dengan ajaran Islam. }\end{array}$ \\
\hline
\end{tabular}




\begin{tabular}{|c|c|c|}
\hline 9 & $\begin{array}{l}\text { Timbul Raharjo, } \\
\text { "Cokro } \\
\text { Manggilingan", } \\
\text { Besi, Powder } \\
\text { coating, } \\
110 \times 100 \times 40 \mathrm{~cm} \text {, } \\
2009\end{array}$ & $\begin{array}{l}\text { Kehidupan penuh dinamika kadang diatas } \\
\text { kadang dibawah, jangan menangis ketika } \\
\text { dilanda kesusahan, kemiskinan, namun } \\
\text { eling lan waspodo ketika banyak harta. }\end{array}$ \\
\hline 10 & $\begin{array}{l}\text { Titiana Irawani, } \\
\text { "Matahariku",Perun } \\
\text { ggu, } \\
57 \times 45 \times 15 \mathrm{~cm}, 2009\end{array}$ & $\begin{array}{l}\text { Karya ini terimpirasi dari pernik-pernik } \\
\text { ornamen yang ada pada reflector } \\
\text { blencong. Bentuk yang menyerupai kaki } \\
\text { hewan, manusia, tumbuh-tumbuhan dan } \\
\text { bentuk bulatan pada bagian atas sebagai } \\
\text { matahari adalah simbol dari kehidupan } \\
\text { dunia. Bentuk piring cekung pada bagian } \\
\text { cucuk sebagai simbol bahwa kehidupan ini } \\
\text { dibutuhkan suatu wadah atau tempat } \\
\text { untuk hidup. Untuk itulah matahari } \\
\text { sumber dari segala kehidupan. }\end{array}$ \\
\hline 11 & $\begin{array}{l}\text { Ponomin, } \\
\text { "The Burnet of } \\
\text { Alengka Kingdom", } \\
\text { Stoneware, glazuur, } \\
100 \times 100 \times 100 \mathrm{~cm}, \\
2009\end{array}$ & $\begin{array}{l}\text { Dalam adengan anoman obong yang } \\
\text { mengandung nilai filosofis setiap } \\
\text { perbuatan akan menanggung akibat (sopo } \\
\text { Nggawe nganggo) dalam perwujudannya } \\
\text { mengomposisikan garis dan biadang } \\
\text { menggeliat keatas sebagai gambaran api } \\
\text { membakar alengka oleh seekor Anoman. }\end{array}$ \\
\hline 12 & $\begin{array}{l}\text { Tri Purwanto, } \\
\text { "Sebuah Pilihan", } \\
\text { kayu, 140x140 cm, } \\
2009\end{array}$ & $\begin{array}{l}\text { Dalam dinamika dan gelombang } \\
\text { kehidupan, kita mempunyai berbagai } \\
\text { pilihan yang sangat sulit dan } \\
\text { membingungkan, dalam keadaan yang } \\
\text { demikian orang akan mencari ketentraman } \\
\text { dan kedamaian. Dengan berpijak pada lima } \\
\text { waktu yang telah ditentukan dengan } \\
\text { Sembilan syahadat sehari maka akan } \\
\text { terbukalah sebuah pencerahan dan jalan } \\
\text { yang membutuhkan sarana } \\
\text { yaitu"lima"hingga timbul kebersamaan } \\
\text { dalam bingkai kedamaian, ketentraman, } \\
\text { senasib sepenanggungan. }\end{array}$ \\
\hline 13 & $\begin{array}{l}\text { Djandjang Purwo } \\
\text { Sedjati, } \\
\text { "Low Profile", } \\
\text { Kayu, } \\
160 \times 108 \mathrm{~cm}, \\
2009\end{array}$ & $\begin{array}{l}\text { Wajah dapat menjadi identiitas dan } \\
\text { pengenal diri seseorang, demikian juga } \\
\text { wajah dapat berubah ubah dalam } \\
\text { berbagai ekspresi sesuai dengan suasana } \\
\text { hati. Seseorang dapat ditebak hatinya } \\
\text { melalui ekspresi wajah. Ketenangan diri } \\
\text { merupakan salah satu cerminan suasana } \\
\text { hati yang dapat diekspresikan oleh wajah } \\
\text { itu sendiri. }\end{array}$ \\
\hline
\end{tabular}




\begin{tabular}{|c|c|c|}
\hline 14 & $\begin{array}{l}\text { Endang Lestari, } \\
\text { "Menjaga Sang ...", } \\
\text { stoneware, kayu, } \\
200 \times 200 \times 150 \mathrm{~cm}, \\
2009\end{array}$ & $\begin{array}{l}\text { Patung anjing } 1 \times 1 \text { ada } 6-7 \text { dalam drum } \\
\text { besar yang posisinya bisa berobah-obah. }\end{array}$ \\
\hline 15 & $\begin{array}{l}\text { Nanang Rochyawan, } \\
\text { "Lek ...Play", } \\
\text { Mix media, } \\
25 \times 11 \times 10 \mathrm{~cm}, 2009\end{array}$ & $\begin{array}{l}\text { Masuknya budaya asing kedalam aspek } \\
\text { kehidupan masyarakat kita, sedikit banyak } \\
\text { menimbulkan nampak positif maupun } \\
\text { negative. Misalnya permainan tradisional } \\
\text { seperti dakon yang telah di geser dengan } \\
\text { permainan modern playstation. Tapi kita } \\
\text { jaganlah lupakan budaya sendiri, kita } \\
\text { diharapkan dapat menyikapi dangan bijak } \\
\text { sana akan pengaruh-pengaruh budaya } \\
\text { asing tersebut. } \\
\text { Dalam karya ini digambarkan sebuah } \\
\text { dakon (permainan tradisional) dengan } \\
\text { mengarahkan setik playstation atau } \\
\text { permainan modern yaitu mengharapkan } \\
\text { kita bisa membayangkan budaya asing dan } \\
\text { budaya kita sendiri yang saling bertemu } \\
\text { kepopulerannya. }\end{array}$ \\
\hline 16 & $\begin{array}{l}\text { Trien Afriza, } \\
\text { "Berebut, merapat, } \\
\text { ayo ikut",Keramik, } \\
\text { kayu,80x70x45cm, } \\
2009\end{array}$ & $\begin{array}{l}\text { Inilah fakta negatif bangsa Indonesia, } \\
\text { hampir setiap lembaga baik dari bawah RT, } \\
\text { RW, sampai lembaga tertinggi seperti DPR, } \\
\text { MPR setiap lima tahun sekali saling } \\
\text { berebut kursi. Banyaknya partai politik } \\
\text { yang menjamur, manusia yang haus } \\
\text { kekuasaan saling berebut kursi menjadi } \\
\text { pemicunya, kondisi ini sanagtlah tumbuh } \\
\text { subur bagai jamur tumbuh ditempat yang } \\
\text { subur, symbol politik kita memang ditandai } \\
\text { dengan perebutan kursi, ayo siapa yang } \\
\text { ikut berebut. }\end{array}$ \\
\hline 17 & $\begin{array}{l}\text { Mareto Dwi H, } \\
\text { "Usia Dini",Kayu } \\
\text { jati, } 70 \times 60 \mathrm{~cm}, 2009\end{array}$ & $\begin{array}{l}\text { Karya Usia Dini ini bertujuan mengajak } \\
\text { masyarakat untuk mulai mewacanakan } \\
\text { pendidikan seks sejak anak masih berusia } \\
\text { dini. Karena dengan memberikan } \\
\text { pendidikan dan wacana tentang seks yang } \\
\text { benar dan sehat sejak usia dini pada anak } \\
\text { akan menjadikan anak lebih mawas diri } \\
\text { dalam menyikapi kehidupan seksnya diusia } \\
\text { dewasa. }\end{array}$ \\
\hline 18 & 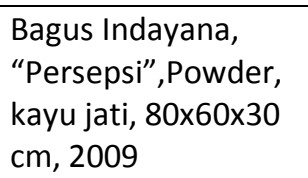 & $\begin{array}{l}\text { Melarung keruwetan hidup menuju } \\
\text { kedamaian abadi }\end{array}$ \\
\hline
\end{tabular}




$19 \begin{aligned} & \text { Alexis, } \\ & \text { "Ritus Daun",Kayu } \\ & \text { jati, } 65 \times 40 \times 40 \\ & \text { cm,2009 }\end{aligned}$

Novianto Bambang
Nugroho."Menjaga"
$200 \times 110 \mathrm{~cm}$. Prima
mesres sanforis
Indigosol, Napthol
dan Rapid,2011

21 Edi Eskak, "Open your mind", limbah kayu mahoni, $97 \times 37 \times 33$ $\mathrm{cm}, 2011$
Selembar daun yang gugur ketanah apakah setelah itu busuk dan hancur dimakan tanah begitu saja, saya melihat dari sisi lain daun merupakan bagian unsur alam yang hidup di dunia ini, gugur ketanah pasti ada tujuan dan sudah ada yang mengaturnya. Bermanfaat untuk kesuburan dan generasi selanjutnya, memberikan manfaat kepada yang ada di muka bumi ini serta untuk keseimbangan alam.

Seorang ibu memiliki peran, tugas, dan tanggung jawab yang besar di dalam sebuah keluarga. Selain menjadi pendamping suami, seorang ibu harus memelihara/merawat, mendidik, dan membesarkan anak-anaknya hingga dewasa. Oleh karena itu seorang ibu harus menyempatkan diri untuk meluangkan waktu untuk bersama anak-anaknya, di tengah kesibukannya bekerja secara professional.

Limbah kayu merupakan sisa dari pembuatan suatu produk, limbah inilah yang dimanfaat sebagai bahan untuk menciptakan karya seni topeng dengan bentuk tiga dimensi, efek sambungan kayu menjadi bentuk karya yang artistik.
Modernisasi teknologi dan perkembangan sains yang sangat pesat, memberi rangsangan yang cukup kuat pada kepekaan rasa cipta karya-karya yang dibuat dan memberi nilai artistik baru serta puistis yang amat "greng".

\begin{tabular}{l}
\hline 23 Indah Chrysanti \\
Angge, \\
"Gemah ripah loh \\
jinawe", kuningan, \\
150x120 cm, 2012
\end{tabular}

Angge, jinawe", kuningan, $150 \times 120 \mathrm{~cm}, 2012$

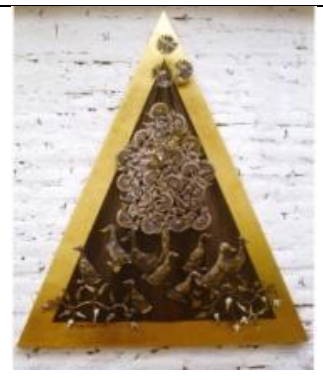

Karya ini terbuat dari bahan kuningan, yang dipangkalkan datas sebuah dasar kayu berbentuk segitiga yang merupakan stilisasi dari bentuk tumbuhan dan binatang, ini menunjukkan jejak ukir bergaya tradisional. Tema yang diusung berpadu dengan penggunaan teknik ukir tradisional kian menunjukkan identitas kebudayaan dan toyalitas yang kuat. 


\begin{tabular}{l}
\hline $24 \quad$ Budi Hartono \\
"Berbeda Tetap \\
Satu" \\
Kuningan \\
$80 \times 25 \times 75 \mathrm{~cm}$ \\
2012
\end{tabular}

\section{Toyibah}

Kusumawati,

Kulit

tersamak, "Dewi

Shinta", 45 × $35 \mathrm{~cm}$,

Kulit Nabati, 2012
Karya terinspirasi dari tokoh wayang kulit gaya Banyumasan bernama Bawor (Bagong). Bawor tercermin dari sifat dan karakter orang Banyumas yang cablaka atau suka berterus terang, apa adanya. Bawor tercipta dari bayang-bayang semar sehingga bentuknya mirip dengan semar sebagai bapak angkatnya. Walaupun punakawan berwajah atau bentuk fisiknya jelek tetapi mereka adalah tempat berkeluh kesah dan pandai menghibur ketika para kesatria sedang berkeluh kesah atau dirundung masalah. Karya ini lebih menonjolkan sifat bawor yang ceria, lucu dan penghibur.

Dalam cerita Ramayana terdapat kisah Rama dan Sinta. Perjalanan kasih asmara mereka, banyak mendapat rintangan dan cobaan. Namun berkat perjuangan Rama dan kesetiaan Shinta, rintangan dan cobaan tersebut dapat diatasi, sehingga kasih asmara mereka dapat terus terjalin. Diangkatnya tokoh Dewi Shinta tersebut sebagai lambang kesetiaan dan diabadikan dalam sebuah karya, dengan bahan kulit. Penggambaran tokoh Dewi Shinta dalam karya di sini tidak sebagaimana mestinya, namun sudah dideformasi

TABEL II.STRUKTUR KARYA SENI KRIYA KONTEMPORER

\begin{tabular}{|c|c|c|c|c|c|}
\hline NO & KARYA & SUMBER IDE & BAHAN & $\begin{array}{c}\text { TEKNIK } \\
\text { PEMBENTUKAN }\end{array}$ & FINISHING \\
\hline (1) & (2) & (3) & (4) & (5) & (6) \\
\hline 1 & 1 & Budaya dan Religi & Tembaga, Plat Besi & Tatah dan Las & $\begin{array}{l}\text { SN dan Slep } \\
\text { Polish }\end{array}$ \\
\hline 2 & 2 & Binatang (Tarantula) & Kain Bercolin & BatikTutup Celup & Warna Naptol \\
\hline 3 & 3 & Binatang (Bekicot) & Alumunium, batu & Cetak Cor & Slep Polish \\
\hline 4 & 4 & $\begin{array}{l}\text { Alat Musik } \\
\text { (Contrbass) }\end{array}$ & $\begin{array}{l}\text { Besi, kaca, } \\
\text { Kuningan }\end{array}$ & Las & Cat Duco \\
\hline 5 & 5 & Motif Tradisional & $\begin{array}{l}\text { Tembaga, Cermin, } \\
\text { Frem Besi }\end{array}$ & Scroll Saw & $\begin{array}{l}\text { SN dan Cat } \\
\text { Emco }\end{array}$ \\
\hline 6 & 6 & Topeng Primitif & Stoneware & Pinch (Pijit) & Bakar Biscuit \\
\hline 7 & 7 & $\begin{array}{l}\text { Motif Tradisional } \\
\text { Dayak }\end{array}$ & $\begin{array}{l}\text { Sterling, Nikel } \\
\text { Silver }\end{array}$ & Patri Perak & Slep Polish \\
\hline 8 & 8 & Ayat Jihad Fisabilillah & Kulit Tersamak & Tatah, Kerok & Cat Air \\
\hline
\end{tabular}




\begin{tabular}{|c|c|c|c|c|c|}
\hline 9 & 9 & Dinamika Kehidupan & $\begin{array}{l}\text { Besi, Powder } \\
\text { Coating }\end{array}$ & Las & Crom Coating \\
\hline 10 & 10 & Blencong & Perunggu & Cetak Cor & Patinasi \\
\hline 11 & 11 & Wayang/Ramayana & Stoneware, Glazur & Pinch, Ukir & $\begin{array}{l}\text { Bakar biscuit, } \\
\text { Glazur }\end{array}$ \\
\hline 12 & 12 & Dinamika Kehidupan & Kayu Jati & Tatah & Politur \\
\hline 13 & 13 & Wajah Manusia & Kayu Jati & Tatah & Politur \\
\hline 14 & 14 & Binatang (Anjing) & $\begin{array}{l}\text { Stoneware Clay, } \\
\text { Wood }\end{array}$ & Cetak Tuang & Glazur \\
\hline 15 & 15 & Permainan anak & Mix Media & Pinch, potong & Cat \\
\hline 16 & 16 & Politik & Ceramik, Wood & Pinch & Glasur \\
\hline 17 & 17 & Kehidupan Sosial & Kayu Jati & Tatah & Politur \\
\hline 18 & 18 & Fenomena Hidup & $\begin{array}{l}\text { Wood Powder, } \\
\text { Teak Wood }\end{array}$ & Tatah dan Tempel & Politur \\
\hline 19 & 19 & Tumbuhan (Daun) & Teak Wood & Tatah dan Bubut & $\begin{array}{l}\text { Melamin } \\
\text { Natural }\end{array}$ \\
\hline 20 & 20 & Kehidupan & Kain katun & batik & Napthol \\
\hline 21 & 21 & Wajah & $\begin{array}{l}\text { Limbah Kayu } \\
\text { Mahoni }\end{array}$ & Tatah dan Press & Politur \\
\hline 22 & 22 & Teknologi Sains & Tembaga & Tatah & $\begin{array}{l}\text { SN (Sulfida } \\
\text { Natrium) }\end{array}$ \\
\hline 23 & 23 & $\begin{array}{l}\text { Tumbuhan dan } \\
\text { Binatang }\end{array}$ & Kuningan & Tatah & SN \\
\hline 24 & 24 & Bawor & Tembaga & Kenteng dan Patri & SN \\
\hline 25 & 25 & Wayang/ramayana & Kulit tersamak & Tatah & Pewarna kulit \\
\hline
\end{tabular}

TABEL III. FUNGSI DAN MAKNA KARYA SENI KRIYA KONTEMPORER

\begin{tabular}{|c|c|c|c|c|c|}
\hline \multirow[t]{2}{*}{ NO } & \multirow{2}{*}{$\begin{array}{l}\text { SAMPEL } \\
\text { KARYA }\end{array}$} & \multicolumn{3}{|c|}{ FUNGSI KARYA } & \multirow[t]{2}{*}{ MAKNA } \\
\hline & & $\begin{array}{l}\text { Praktis/ } \\
\text { fisik }\end{array}$ & $\begin{array}{l}\text { Personal } \\
\text { /Estetis }\end{array}$ & $\begin{array}{c}\text { Sosi } \\
\text { al }\end{array}$ & \\
\hline (1) & (2) & (3) & (4) & (5) & (6) \\
\hline 1 & 1 & - & $\mathrm{v}$ & v & $\begin{array}{l}\text { Kerukunan dalam beragama, jangan sampai } \\
\text { terkoyak oleh kepentingan tertentu. }\end{array}$ \\
\hline 2 & 2 & - & $\mathrm{v}$ & $\mathrm{v}$ & $\begin{array}{l}\text { Saling mengerti satu sama lain untuk mencapai } \\
\text { kehidupan yang damai dan bahagia }\end{array}$ \\
\hline 3 & 3 & - & $v$ & $v$ & $\begin{array}{l}\text { Menentukan pilihan pada saat yang mendesak, } \\
\text { apapun resikonya harus dihadapi dengan } \\
\text { keyakinan yang mantap. }\end{array}$ \\
\hline 4 & 4 & $v$ & $\mathrm{v}$ & $\mathrm{v}$ & $\begin{array}{l}\text { Orang besar adalah orang yang mampu bergaul } \\
\text { dengan berbgai kalangan, seperti halnya } \\
\text { Contrabass yang bisa berbaur dengan alat music } \\
\text { lainnya }\end{array}$ \\
\hline
\end{tabular}




\begin{tabular}{|c|c|c|c|c|c|}
\hline 5 & 5 & $\mathrm{v}$ & $\mathrm{v}$ & $\mathrm{v}$ & $\begin{array}{l}\text { Mengingatkan untuk selalu introspeksi diri apa } \\
\text { yang telah diperbuat di muka bumi sebagai } \\
\text { khalifah. }\end{array}$ \\
\hline 6 & 6 & - & $\mathrm{v}$ & $\mathrm{v}$ & $\begin{array}{l}\text { Topeng kepala suku yang dikelilingi oleh } \\
\text { masyarakatnya. Ter Intepretasi topeng "Sang } \\
\text { tertua" yang menampilkan sulur-sulur ornamentik, } \\
\text { sebuah tafsir atas gagasan spiritual. }\end{array}$ \\
\hline 7 & 7 & $\mathrm{v}$ & $\mathrm{v}$ & $\mathrm{v}$ & $\begin{array}{l}\text { Melestarikan motif tradisional dalam bentuk } \\
\text { perhiasan kontemporer, sebagai usaha pelestarian } \\
\text { dan pengembangan. }\end{array}$ \\
\hline 8 & 8 & - & $\mathrm{v}$ & $\mathrm{v}$ & $\begin{array}{l}\text { Ajakan untuk berjihad dijalan allah apapun } \\
\text { tantangannya dan resiko yang akan dihadapi harus } \\
\text { tetap dilakukan dengan keyakinan penuh atas } \\
\text { keridhoan Allah. }\end{array}$ \\
\hline 9 & 9 & - & $\mathrm{v}$ & $\mathrm{v}$ & $\begin{array}{l}\text { Mengingatkan kita untuk selalu ingat dan waspada } \\
\text { dalam keehidupan yang penuh dinamika, kadang } \\
\text { diatas kadang dibawah, baik buruk itu selalu ada } \\
\text { dalam kehidupan. }\end{array}$ \\
\hline 10 & 10 & $\mathrm{v}$ & $\mathrm{v}$ & $\mathrm{v}$ & $\begin{array}{l}\text { Matahari adalah simbol dari kehidupan, karena } \\
\text { matahari sumber dari segala kehidupan. }\end{array}$ \\
\hline 11 & 11 & - & $\mathrm{v}$ & $\mathrm{v}$ & $\begin{array}{l}\text { Anoman obong mengandung nilai filosofis setiap } \\
\text { perbuatan akan menanggung akibatnya }\end{array}$ \\
\hline 12 & 12 & - & $\mathrm{v}$ & $\mathrm{v}$ & $\begin{array}{l}\text { Dinamika dan gelombang kehidupan, kita } \\
\text { mempunyai berbagai pilihan yang sangat sulit dan } \\
\text { membingungkan, dalam keadaan yang demikian } \\
\text { orang akan mencari ketentraman dan kedamaian. } \\
\text { Dengan berpijak pada lima waktu yang telah } \\
\text { ditentukan. }\end{array}$ \\
\hline 13 & 13 & - & $\mathrm{v}$ & v & $\begin{array}{l}\text { Seseorang dapat ditebak hatinya melalui ekspresi } \\
\text { wajah. Ketenangan diri merupakan salah satu } \\
\text { cerminan suasana hati yang dapat diekspresikan } \\
\text { oleh wajah itu sendiri. }\end{array}$ \\
\hline 14 & 14 & - & $\mathrm{v}$ & $\mathrm{v}$ & $\begin{array}{l}\text { Menggambarkan kerukunan dalam suatu ruang } \\
\text { yang saling hormat menghormati satu dengan } \\
\text { lainnya. }\end{array}$ \\
\hline 15 & 15 & - & $\mathrm{v}$ & $\mathrm{v}$ & $\begin{array}{l}\text { Jaganlah lupakan budaya sendiri, kita diharapkan } \\
\text { dapat menyikapi dangan bijaksana akan pengaruh- } \\
\text { pengaruh budaya asing tersebut. }\end{array}$ \\
\hline 16 & 16 & - & $\mathrm{v}$ & $\mathrm{v}$ & $\begin{array}{l}\text { Banyaknya partai politik yang menjamur, manusia } \\
\text { yang haus kekuasaan saling berebut kursi menjadi } \\
\text { pemicunya, simbol politik kita memang ditandai } \\
\text { dengan perebutan kursi, ayo siapa yang ikut } \\
\text { berebut. }\end{array}$ \\
\hline 17 & 17 & - & $\mathrm{v}$ & $\mathrm{v}$ & $\begin{array}{l}\text { Dengan memberikan pendidikan dan wacana } \\
\text { tentang seks yang benar dan sehat sejak usia dini }\end{array}$ \\
\hline
\end{tabular}




\begin{tabular}{|c|c|c|c|c|c|}
\hline & & & & & $\begin{array}{l}\text { pada anak akan menjadikan anak lebih mawas diri } \\
\text { dalam menyikapi kehidupan seksnya diusia } \\
\text { dewasa. }\end{array}$ \\
\hline 18 & 18 & - & $\mathrm{v}$ & $\mathrm{v}$ & $\begin{array}{l}\text { Melarung keruwetan hidup menuju kedamaian } \\
\text { abadi }\end{array}$ \\
\hline 19 & 19 & - & $\mathrm{v}$ & $\mathrm{v}$ & $\begin{array}{l}\text { Daun merupakan bagian unsure alam yang hidup } \\
\text { didunia ini, gugur ketanah pasti ada tujuan dan } \\
\text { sudah ada yang mengaturnya. Bermanfaat untuk } \\
\text { kesuburan dan generasi selanjutnya, memberikan } \\
\text { manfaat kepada yang ada dimuka bumi ini serta } \\
\text { untuk kesimbangan alam. }\end{array}$ \\
\hline 20 & 20 & - & v & $\mathrm{v}$ & $\begin{array}{l}\text { mengingatkan akan tugas utama seorang ibu } \\
\text { rumahtangga untuk mengasuh, menjaga anak- } \\
\text { anaknya. }\end{array}$ \\
\hline 21 & 21 & - & $\mathrm{v}$ & $\mathrm{v}$ & $\begin{array}{l}\text { Supaya limbah itu bisa dimanfaatkan menjadi } \\
\text { sebuah karya seni, tidak hanya menjadi sampah } \\
\text { yang merusak pandangan. }\end{array}$ \\
\hline 22 & 22 & - & $\mathrm{v}$ & $\mathrm{v}$ & $\begin{array}{l}\text { Modernisasi teknologi dan perkembangan sains } \\
\text { yang sangat pesat, memberi rangsangan yang } \\
\text { cukup kuat pada kepekaan rasa cipta karya-karya } \\
\text { yang dibuat dan memberi nilai artistik baru. }\end{array}$ \\
\hline 23 & 23 & - & $\mathrm{v}$ & $\mathrm{v}$ & $\begin{array}{l}\text { menunjukkan identitas kebudayaan melalui seni } \\
\text { ukir tradisional. }\end{array}$ \\
\hline 24 & 24 & - & $\mathrm{v}$ & $\mathrm{v}$ & $\begin{array}{l}\text { Sebagai usaha pengembangan seni tradisional } \\
\text { bawor supaya tidak hilang ditelan jaman. }\end{array}$ \\
\hline 25 & 25 & - & $\mathrm{v}$ & $\mathrm{v}$ & $\begin{array}{l}\text { Betapa besar arti cinta dan kesetiaan antara suami } \\
\text { dan istri (Rama dan Sinta). }\end{array}$ \\
\hline
\end{tabular}

\section{Eksplorasi Karya}

\section{a. Eksplorasi Ide}

Pada tabel III, apa yang menjadi sumber ide dari karya-karya yang diteliti dapat diidentifikasi meliputi: figure/kehidupan manusia manusia, kehidupan hewan (fauna), tumbuhan (flora), budaya tradisi, kaligrafi arab, masalah sosial politik, dan religi. Hal ini menunjukkan bahwa karya seni kriya telah menjadi wahana berekspresi secara bebas bagi para senimannya, yang mengangkat berbagai fenomena kehidupan manusia sehari-hari.

Karya-karya yang dijadikan sampel yang mengambil sumber ide dari fenomena kehidupan manusia dapat dilihat pada table 3 lajur 3, yaitu pada sampel no 4, $8,10,12,16,17,18$, dan 20. Sebagai contoh, sampel karya nomor 1 yang berjudul "Hikayat Ikonositas" yang inspirasinya bersumber dari konflikkonflik social keagamaan, memiliki makna pentingnya kerukunan dalam 
beragama, jangan sampai terkoyak oleh kepentingan tertentu.

\section{b. Eksplorasi Bahan}

Pada table III dapat diidentifikasi bahwa bahan-bahan yang digunakan untuk pembuatan karya-karya kriya terdiri dari berbagai jenis bahan sebagaimana lazimnya yang dipakai pada umumnya. Sebagaimana dapat dilihat pada lajur 4 yang menunjukkan bahwa bahan-bahan yang digunakan meliputi: logam (tembaga, kuningan, perak/silver, besi, perunggu, dan alumunium; kayu (jati, mahoni); kain katun (berkolin, primissima); tanah liat (stone ware), kulit (kulit tersamak). Terdapat juga beberapa karya sampel yang menggunakan beberapa bahan/mix media, seperti pada karya sampel nomor 3 (alumunium, batu), nomor 14 (tanah liat/stone ware, kayu), nomor 15 (tanah liat/stone ware, logam, alat PS), kayu, logam, kanvas).

Berdasarkan data tersebut dalam table III menunjukkan bahwa dalam aspek eksplorasi bahan, para seniman kriya pada umumnya masih terikat dengan bahan-bahan sebagaimana yang telah biasa digunakan atau bahanbahan konvensional, walaupun ada beberapa karya yang dibuat dengan menggunakan beberapa bahan yang berbeda /mixmedia tetapi masih merupakan bahan yang sudah biasa dipakai dalam seni kriya.

a. Eksplorasi Teknik
Masih dalam tabel III, teknik yang dipakai dalam pembuatan karya disajikan dalam lajur 5. Terdapat berbagi macam teknik yang dieksplor dalam pembuatan karya kriya. Teknik tatah atau dapat juga disebut dengan teknik ukir yang dipakai dalam pembuatan karya yang menggunakan bahan dari kayu, logam, atau kulit. Teknik tatah/ukir kayu diterapkan pada pembuatan karya yang terbuat dari kayu yang biasanya disebut dengan teknik ukir kayu, dan yang diterapkan untuk pembuatan karya yang terbuat dari logam biasa disebut dengan teknik ukir logam, tetapi apabila diterapkan untuk pembuatan karya yang dibuat dari bahan kulit biasa disebut dengan teknik tatah sungging kulit.Teknik tatah/ukir digunakan pada pembuatan karya sampel nomor $1,8,11,12,13,17$, 18, 22, 23, dan 25. Berdasrkan data tersebut menunjukkan bahwa penggunaan teknik-teknik tatah/ukir tersebut disesuaikan dengan bahan yang dipakai. Dalam hal ini masalah teknik memang tidak dapat dipisahkan dengan bahan yang digunakan.

\section{b. Eksplorasi Bentuk}

Bentuk dan dimensinya, yaitu karya dua dimensional dan karya tiga dimensional. Karya dua dimensional memiliki bentuk datar dan hanya memiliki ukuran panjang dan lebar, karena adanya optical illution maka akan kelihatan memiliki kesan volume, kedalaman dan ruang. Karya tiga dimensional memiliki bentuk yang 
benar-benar memakan ruang dan memiliki ukuran panjang, lebar serta tebal. Karya tiga dimensional disebut juga dengan istilah seni spasial (spatial art form) karena ketiga dimensinya harus benar-benar diperhatikan.

Berdasarkan data pada tabel III menunjukkan bahwa karya-karya kriya memiliki bentuk dua dimensi dan tiga dimensi. Karya dua dimensi dapat dilihat pada karya sampel nomor $1,2,5,6,7,8$, $12,13,17,18,22,23$, dan 25 . Sedangkan karya-karya dengan bentuk tiga dimensional dapat dilihat pada sampel nomor $3,4,9,10,11,14,15,16,18$, 19,21, dan 24.

\section{c. Eksplorasi Fungsi}

Menurut landasan teori yang dikemukakan Feldman di depan bahwa fungsi karya seni meliputi fungsi personal, fungsi social, dan fungsi fisik (the function of art: personal, social, physical) Data eksplorasi fungsi karya kriya disajikan pada table IV menunjukkan bahwa semua karya yang dijadikan sampel memiliki fungsi personal dan fungsi sosial. Dikatakan memiliki fungsi personal karena semua karya dibuat oleh para senimannya merupakan ekspresi pribadi senimannya, sedangkan dikatakan memiliki fungsi social karena semua karya memiliki makna-makna yang merupakan pesan-pesan untuk masyarakat yang melihatnya. Tampak adanya kecenderungan karya yang memiliki fungsi social, seperti kritik social, pesan-pesan moral, dan pesan- pesan religious. Selain itu sebagai karya seni kriya, masih berorientasi pada aspek estetik yang mengutamakan keindahan bentuknya. Sedikit karya sampel yang dibuat untuk tujuan memiliki fungsi fisiknya atau untuk memenuhi kebutuhan praktis atau memiliki fungsi praktis. Karya-karya sampel yang memiliki fungsi fisik/praktis adalah karya sampel nomor 4, 5, 7, dan 10.

\section{d. Eksplorasi Gaya}

Gaya (style/idiom), yang mengacu pada pengertian perorangan maupun kelompok dalam periode tertentu, kebudayaan tertentu atau kawasan regional tertentu (Humar Sahman, 1993: 37-40). Eksplorasi gaya dapat dikaji berdasarkan tabel II yang memuat gambar karya yang diteliti. Tradisi seni kriya masa lalu yang selalu berorientasi pada gaya dekoratif (stylasi flora, fauna, manusia) tidak lagi menjadi perhatian para seniman kriya masa kini. Berdasarkan data pada table II tampak adanya gaya perorangan atau gaya pribadi senimannya dengan variasi gaya yang bebas, sesuai dengan ekspresi masing-masing senimannya.

\section{Eksperimentasi Karya}

Di dalam memahami seni diungkapkan bahwa jika seni harus dilihat sebagai kegiatan mereproduksi realitas, maka reproduksi itu masih harus memperlihatkan campur tangan penciptanya. Seni dapat pula dilihat 
sebagai aktifitas mengungkap perasaan atau emosi penciptanya, sehingga menjadi karakteristik dalam arti mencerminkan kehidupan perasaan penciptanya. Selanjutnya di ungkapkan pula bahwa pengertian apapun yang hendak dilekatkan pada seni, maka representasi, interpretasi, kondensasi, konsentrasi, intensifikasi, konkretisasi, aktualisasi, kontemplasi, iluminasi, personifikasi; kesemuanya harus tertuang di dalam bentuk dan strukturnya (Humar Sahman, 1993: 21). Jadi apa yang disebut karya seni itu sesungguhnya dapat dilihat sebagai perpaduan antara wujud lahiriah yang bisa diamati dan perasaan terhadap nilai tertentu yang berdemensi ruhaniah. Wujud lahiriah ini lewat ciri-ciri lahiriahnya membabarkan atau mengejawantahkan sikap batin atau perasaan terhadap nilai tertentu. Begitu pula halnya dengan sikap batin itu akan memperoleh wujudnya yang harmonis secara langsung. Proses eksternalisasi yang internal secara langsung ini disebut ekspresi simbolik (Humar Sahman, 1993: 29).

Kajian eksperimentasi atas karya kriya kontemporer difokuskan pada aspek proses perwujudannya, bagaimana ide-ide para seniman kriya yang diperoleh dari berbagai sumber dan sangat variatif diwujudkan menjadi karya seni. Ide masing-masing seniman diwujudkan dengan media dan teknik yang sesuai dengan pilihan dan penguasaan atas pembagian bidang seni kriya yang ada. Seperti diketahui bahwa bidang seni kriya dapat dikategorikan menjadi lima jenis, yaitu kriya kayu, kriya logam, kriya kulit, kriya tekstil/batik, dan kriya keramik. Masingmasing jenis tersebut terdapat karya yang dijadikan sampel penelitian ini. Dalam pembuatannya, masing-masing jenis tersebut memerlukan ketrampilan dan penguasaan teknik yang berbedabeda sesuai dengan bahan yang diolahnya. Hasil karya yang diperoleh dari masing-masing jenispun tentu berbeda-beda pula tergantung pada bagaimana ekspresi simbolik dari senimannya. Karya-karya yang dibuat tidak sekedar sebagai hiasan saja, tetapi memiliki makna-makna tertentu dan diberi judul sesuai dengan maksud penciptaannya, bentuk karyanya, dan makna yang dikandungnya. Jadi dalam hal ini karya seni kriya sebagai kegiatan mereproduksi realitas, maka reproduksi itu masih harus memperlihatkan campur tangan penciptanya. Seni dapat pula dilihat sebagai aktifitas mengungkap perasaan atau emosi penciptanya, sehingga menjadi karakteristik dalam arti mencerminkan kehidupan perasaan penciptanya.

Berdasarkan kategori jenis karya seni kriya tersebut di atas, di dalam melakukan eksperimentasi dalam perwujudan karya-karyanya dapat diuraikan sebagai berikut.

\section{a. Kriya kayu.}

Karya-karya kriya kayu yang dijadikan sampel dalam penelitian ini 
dapat dilihat pada table I, yaitu sampel nomor $12,13,17,18,19$, dan 21 . Karyakarya tersebut terinspirasi dari adanya permasalahan-permasalahan sosial dalam kehidupan sehari-hari. Eksperimentasi mereka lakukan dengan menggunakan bahan kayu. Pemilihan bahan kayu sebagai media ciptaannya disebabkan oleh latar belakang studinya yaitu di minat utama Kriya Kayu.

Di dalam mengekspresikan dan mewujudkan gagasannya, mereka menggunakan bentuk-bentuk atau simbol-simbol sesuai dengan karakter masing-masing. Tidak terdapat bentuk yang menggunakan unsur-unsur ornament tradisional, kecualai karya sampel no 5, dan 7 yang di dalamnya terdapat unsur bentuk ikal. Karya-karya tersebut diwujudkan dengan teknik ukir/pahat, dan ada yang menggunakan teknik bubut (karya sampel nomor 19). Teknik finishing yang digunakan ada yang memilih mempertahankan karakter bahan kayunya (natural) seperti karya sam[pel nomor 18, 19, dan 21 dan ada pula yang bahan finishing cat, prada emas/perak yang menutup permukaan kayunya (karya sampel nomor 12, 13, dan 17).

Berdasarkan kajian tersebut menunjukkan bahwa eksperimentasi di dalam karya kriya kayu dilakukan dengan berbagai variasi, baik dalam hal bahan, teknik, dan bentuknya.

\section{b. Kriya Logam}

Karya-karya kriya logam yang dijadikan sampel terdapat pada tabel I, yaitu sampel karya nomor 1, 3, 4, 5, 7, 9, 10, 22, 23, dan 24. Untuk karya kriya logam, eksperimentasi perwujudannya dilakukan dengan berbagai bentuk, teknik, dan tampilan. Dari sampel karya tersebut terdapat 3 buah karya panel/dua dimensional, 4 buah karya tiga dimensional, 1 buah perhiasan, dan 1 buah pigura kaca. Dalam mewujudkan ide-idenya, para seniman kriya logam dapat memilih berbagai macam bahan seperti tembaga, kuningan, perak, besi, dan sebagainya yang masing-masing bahan tersebut juga harus dikerjakan dengan teknik-teknik yang sesuai dengan karakternya. Karena bahan logam itu dapat dikerjakan dengan dipotong, disambung, dilubang, dicairkan (cetak tuang), diukir, ditempa, dilapisi, maka seniman kriya logam memiliki banyak pilihan untuk melakukan eksperimentasi dalam menciptakan karyanya.

Sampel karya kriya logam nomor 1 yang berjudul "Hikayat Ikonositas" karya Ahmad Nizam dapat dipakai sebagai contoh sebuah eksperimentasi perwujudan ide melalui media logam berupa plat besi dan lempengan tembaga. Dalam karya tersebut tampak adanya eksplorasi atas karakteristik bahan yang dapat dilipat, ditekuk, diukir, ditempa, dipotong, disambung (patri, las), diwarna.

\section{c. Kriya Keramik}

Sampel karya kriya keramik dalam penelitian ini adalah karya sampel nomor 6, 11,14, 15, dan 16 Ke lima karya 
tersebut merupakan sebuah eksperimentasi yang ingin menggambarkan atau mewujudkan ide/gagasan melalui media tanah liat. Tanah liat memiliki tingkat elastisitas yang tinggi sehingga mudah dibentuk sesuai dengan keinginan senimannya. Seperti karya sampel nomor 6 yang berjudul "Topeng Sang Tertua I" dengan bentuk wajah (abstrak) dengan sulursulur ornamentik dibagian sisi kirinya, adalah hasil eksperimentasi untuk menggambarkan topeng tokoh kepala suku yang sangat dipatuhi oleh masyarakat di sekelilingnya.

Bentuk karya lainnya yang hampir serupa dengan karya di atas adalah sampel karya nomor 11 yang berjudul "The burned of Alengka Kingdom" merupakan hasil eksperimentasi untuk menggambarkan adegan salah satu episode cerita Ramayana (Anoman obong). Karya tersebut dibuat dengan beberapa bagian/komponen seperti tokoh Anoman, lidah api, dan bangunan terbakar, yang diletakkan dengan komposisi yang dinamis dalam posisi yang dapat diubah-ubah. Hal ini hampir sama dengan karya sampel nomor 14 yang displaynya dapat dikomposisi dengan peletakan yang berubah-ubah pula. Perbedaannya, karya sampel nomor 14yang dibuat dengan bentuk realistic, anjing-anjing dibuat dengan bentuk yang menyerupai aslinya.

Berbeda dengan karya lainnya, sampel karya nomor 15 yang berjudul "Lek...Play" merupakan karya kriya keramik yang menggunakan media campuran berupa plat logam dan play station stick. Media tanah liat digunakan untuk pembuatn bodi dan bentuk alat dakon (jenis permainan tradisional). Penggunaan media logam berupa plat untuk pembuatan elemen lung-lungan dengan daun-daun dimaksudkan untuk mewakili kekayaan tradisi yang kita miliki. Sebuah karya dengan mix media yang cukup berani dalam penggunaan media yang belum banyak digunakan di dalam kriya keramik.

\section{d. Kriya Kulit}

Bahan kulit memiliki keterbatasan di dalam penggunaannya, disebabkan oleh sifat fisik yang dimilikinya. Terdapat dua jenis bahan kulit yang biasanya dipakai untuk bahan pembuatan karya kriya, yaitu kulit perkamen dan kulit tersamak. Kulit perkamen biasanya dipakai dalam pembuatan wayang kulit dan sejenisnya, sedangkan kulit tersamak biasanya digunakan untuk pembuatan produk tas, dompet dan sejenisnya.

Dalam penelitian ini terdapat dua buah karya kriya kulit yang dijadikan sampelnya, yaitu sampel karya nomor 8 yang berjudul "Gelora Perjuangan" dan karya sampel nomor 25 yang berjudul "Dewi Sinta". Kedua karya tersebut merupakan hasil eksperimentasi dari senimannya yang keduanya menggambarkan sebuah perjuangan. Sampel karya nomor 8 menggambarkan adanya semangat dalam berjihad, sedangkan lainnya menggambarkan adanya perjuangan untuk 
mempertahankan kesetiaan dan kesucian cinta. Secara visual kedua karya tersebut memiliki kesamaan dalam pemilihan bahan, teknik, dan perwujudannya. Eksplorasi bentuk tradisional seperti lidah api, gunungan, dan wayang (figur tokoh Dewi Sinta) tampak pada kedua karya tersebut. Hal ini menunjukkan adanya upaya untuk tetap menghadirkan local genius dalam karya seni kriya kontemporer.

\section{e. Kriya Tekstil}

Sampel karya nomor 2, dan 20 adalah karya kriya tekstil yang dibuat dengan teknik batik. Kedua karya tersebut berbentuk panel/dua dimensional yang merupakan hasil dari eksperimentasi untuk menggambarkan kehidupan; karya sampel nomor 2 yang berjudul "Berpisah" menggambarkan kehidupan binatang (tarantula), sedangkan karya sampel nomor 20 yang berjudul " Menjaga” menggambarkan kehidupan manusia (ibu). Kedua karya tersebut menggunakan teknik batik, tetapi tidak lagi menggunakan elemen visual berupa motif-motif yang ornamentik sebagaimana terdapat pada karya seni batik tradisional. Jadi dalam karya kriya tekstil kontemporer, teknik batik digunakan untuk mewujudkan gagasan ke dalam bentuk visual.

\section{PENUTUP}

Dari hasil pembahasan atas eksplorasi dan eksperimentasi pada karya-karya seni kriya kontemporer yang dijadikan sampel dalam penelitian ini dapat disimpulkan berdasarkan aspek-aspek yang dikaji sebagai berikut. Sumber ide karya seni kriya banyak yang mengangkat berbagai fenomena kehidupan manusia sehari-hari, sehingga seni kriya telah menjadi wahana berekspresi secara bebas bagi para senimannya. Para seniman kriya pada umumnya masih terikat dengan bahan-bahan sebagaimana yang telah biasa digunakan atau bahan-bahan konvensional, walaupun ada beberapa karya yang dibuat dengan menggunakan beberapa bahan yang berbeda /mixmedia tetapi masih merupakan bahan yang sudah biasa dipakai dalam seni kriya. Teknik pengerjaan karya tidak dapat dipisahkan dengan bahan yang digunakan, maka terdapat berbagai macam teknik produksi kriya yang diterapkan. Karya-karya kriya memiliki bentuk dua dimensi dan tiga dimensi.

Tampak adanya kecenderungan karya yang memiliki fungsi social, seperti kritik social, pesan-pesan moral, dan pesan-pesan religious. Selain itu sebagai karya seni kriya, masih berorientasi pada aspek estetik yang mengutamakan keindahan bentuknya. Sedikit karya sampel yang dibuat untuk tujuan memiliki fungsi fisiknya atau untuk memenuhi kebutuhan praktis atau memiliki fungsi praktis. Dikaji dari aspek gaya menunjukkan adanya gaya perorangan atau gaya pribadi senimannya dengan variasi gaya yang 
bebas, sesuai dengan ekspresi masingmasing senimannya.

Ide masing-masing seniman diwujudkan dengan media dan teknik yang sesuai dengan pilihan dan penguasaan atas pembagian bidang seni kriya yang ada. Berdasarkan kajian menunjukkan bahwa eksperimentasi di dalam karya kriya kayu dilakukan dengan berbagai variasi, baik dalam hal bahan, teknik, dan bentuknya. Untuk karya kriya logam, karena bahan logam itu dapat dikerjakan dengan dipotong, disambung, dilubang, dicairkan (cetak tuang), diukir, ditempa, dilapisi, maka seniman kriya logam memiliki banyak pilihan untuk melakukan eksperimentasi dalam menciptakan karyanya. Demikian pula pada kriya keramik, karena tanah liat memiliki tingkat elastisitas yang tinggi, mudah dibentuk sesuai dengan keinginan senimannya, sehingga menghasilkan karya-karya yang bervariatif. Karyakarya kriya kulit menunjukkan adanya upaya untuk tetap menghadirkan local genius dalam karya seni kriya kontemporer yang diwujudkan dengan teknik konvensional (tatah sungging). Dalam kriya tekstil tetap menggunakan teknik batik, tetapi tidak lagi menggunakan elemen visual berupa motif-motif yang ornamentik sebagaimana terdapat pada karya seni batik tradisional. Berdasarkan kajian dalam penelitian ini menegaskan bahwa karya-karya tersebut cenderung sebagai karya ekspresi dan dengan dasar ini maka ia termasuk dalam frame kriya kontemporer (Anusapati, 2004: 5).

\section{Daftar pustaka.}

Anusapati, Sudjud Dartarto, Operasi Rahman Mochammad., 2004, "Objecthood : Rekoleksi dan Reuni Objek-objek", Katalog, Pameran Kriya Kontemporer 27 September - 7 Oktober 2004 di Taman Budaya Yogyakarta.

Burhan, M. Agus, (Ed.), 2006, Jaringan Makna: Tradisi Hingga Kontemporer, Yogyakarta: BP ISI Yogyakarta.

Feldman, Edmund Burke, 1967, Art as Image and Idea, Englewood Cliffs, New Jersey: Prentice-Hall, Inc.

Gustami SP , 1991, "Seni Sebagai Ujud dan Gagasan", tidak diterbitkan, terjemahan dari Feldman, Edmund Burke, 1967, Art as Image and Idea, Englewood Cliffs, New Jersey: Prentice-Hall, Inc.

Marianto, Dwi, 2002, Seni Kritik Seni, Yogyakarta : Lembaga Penelitian ISI Yogyakarta.

Sahman, Humar, 1993, Mengenali Dunia Seni Rupa, Semarang : IKIP Semarang Press.

Supangkat, Jim, Sumartono, Asmudjo Jono Irianto, Rizki A. Zaelani, M. Dwi Marianto, 2000, Outlet Yogya Dalam Peta Seni Rupa 
80 ] CORAK Jurnal Seni Kriya Vol. 4 No.1, Mei-Okteber 2015

Kontemporer Indonesia,

Yogyakarta :Penerbit Yayasan Seni

Cemeti. 